\section{First Case Report of Aseptic Meningitis Induced by Adalimumab Administered for Treatment of Chronic Plaque Psoriasis}

Wang DY, Chong WS, Pan JY, Heng YK

National Skin Centre, Singapore

J Investig Allergol Clin Immunol 2017; Vol. 27(3): 183-185 doi: $10.18176 /$ jiaci.0148

Key words: Adalimumab. Psoriasis. Aseptic meningitis. Tumor necrosis factor $\alpha$ inhibitors.

Palabras clave: Adalimumab. Psoriasis. Meningitis aséptica. Inhibidores del factor de necrosis tumoral alfa.

Biologic treatments for psoriasis are rarely associated with adverse events [1]. The neurological adverse effects of tumor necrosis factor $\alpha$ inhibitors (TNF $\alpha-i)$ include headache, demyelinating events in the central or peripheral nervous system, and aseptic meningitis [2]. Aseptic meningitis is rare and has been reported primarily in patients receiving $\mathrm{TNF} \alpha-\mathrm{i}$ for rheumatoid arthritis and inflammatory bowel disease.

We present a probable case of $\mathrm{TNF} \alpha$-i-associated aseptic meningitis (TAAM) in a patient with psoriasis.

The patient was a 40-year-old woman who had undergone sleeve gastrectomy for obesity 7 years earlier and had a 5-year history of psoriasis that had proven refractory to ciclosporin (up to $250 \mathrm{mg} / \mathrm{d}$ [ $4.4 \mathrm{mg} / \mathrm{kg}$ ideal body weight/d]) during the preceding 15 months. Adalimumab was added, and the dose of ciclosporin was reduced $(200 \mathrm{mg} / \mathrm{d})$. She received the first dose of adalimumab $80 \mathrm{mg}$ (Humira, AbbVie Inc) without complications; the second dose of $40 \mathrm{mg}$ was administered 1 week later. She was not receiving other concurrent medication.

Eleven days after the initiation of adalimumab, the patient developed persistent frontotemporal headaches, vomiting, photophobia, neck ache, and fever. Examination of the other organ systems was unremarkable. There was no travel history of note. Her son had recently been diagnosed with hand, foot, and mouth disease (HFMD), although the onset of her symptoms had preceded that of her son's by a few days, and she had denied any mucocutaneous complaints that might be indicative of HFMD.

A neurological examination revealed mild nuchal rigidity without focal deficits. The skin examination revealed psoriatic plaques over her trunk and thighs and within intertriginous areas. There were no mucocutaneous signs of HFMD.

She was treated presumptively for meningoencephalitis with intravenous ceftriaxone, ampicillin, and acyclovir. Serum C-reactive protein was moderately elevated $(47.5 \mathrm{mg} / \mathrm{L}$ [reference range, $\leq 5 \mathrm{mg} / \mathrm{L}]$ ) and the complete blood count revealed hemoglobin of $9.6 \mathrm{~g} / \mathrm{dL}(11-15 \mathrm{~g} / \mathrm{dL})$, a white cell count of $9.5 \times 10^{9} / \mathrm{L}\left(3.6-9.3 \times 10^{9} / \mathrm{L}\right)$, and a platelet count of $516 \times 10^{9} / \mathrm{L}\left(170-420 \times 10^{9} / \mathrm{L}\right)$.

Contrast magnetic resonance imaging showed nonspecific scattered foci of cerebral leukoaraiosis that were unrelated to her presenting complaint. Opening pressure on lumbar puncture was $23 \mathrm{cmH}_{2} \mathrm{O}$; cerebrospinal fluid (CSF) analysis revealed 752 red cells $/ \mu \mathrm{L}(<1$ cell $/ \mu \mathrm{L})$ and 37 nucleated cells $\mu \mathrm{L}(0-5$ cells $/ \mu \mathrm{L}), 64 \%$ of which were lymphocytes. $\mathrm{CSF}$ protein was elevated at $0.84 \mathrm{~g} / \mathrm{L}$ (0.1-0.4 g/L), but CSF glucose levels were within normal limits. Findings for Gram stain, bacterial culture, and complement fixation testing for herpes simplex virus, mumps virus, and measles virus in CSF were all unremarkable. The result of polymerase chain reaction assay to detect herpes simplex virus in CSF was also negative.

In view of the recent initiation of adalimumab, TAAM could be not excluded, and adalimumab was therefore discontinued; ciclosporin $(200 \mathrm{mg} / \mathrm{d})$ was maintained. Antimicrobial therapies were stopped when the results of the CSF and blood microbiological studies proved to be negative. The patient improved gradually over 1 week, with eventual resolution of her symptoms and no neurological sequelae. Adalimumab was withheld indefinitely, with no further recurrences.

Based on the clinical course and CSF studies, the patient was diagnosed with aseptic meningitis. The close temporal relationship between initiation of adalimumab and the onset of neurological symptoms, as well as the gradual recovery upon cessation of adalimumab, indicates that the drug was the probable cause. Moreover, meningitis caused by human enterovirus 71 in the absence of mucocutaneous features of HFMD has a frequency of only $1 \%$ [3], thus making it less likely to be the cause in the present case.

Drug-induced aseptic meningitis is rare, with 194 cases identified in the literature [4]. Increasing use of monoclonal antibodies, including cetuximab, efalizumab, and TNF $\alpha-i$, has made these agents an emerging cause of drug-induced aseptic meningitis [4].

A MEDLINE search revealed 6, 3, and 1 case reports of TAAM attributed to infliximab, adalimumab, and etanercept, respectively (Table). TAAM differs from other causes of drug-induced aseptic meningitis in that there is no female preponderance and CSF pleocytosis can be either lymphocyte-predominant or neutrophil-predominant. Most cases of TAAM resolved within 21 days of drug cessation. Only 1 of the 10 cases of TAAM occurred in the context of psoriatic arthritis. Notably, the additional findings of CSF oligoclonal bands, radiographic features of demyelination, and positive antinuclear antibody titers confounded the diagnosis of TAAM [5]. Moreover, neurologic symptoms began after only 20 doses of adalimumab. In the present report, the close temporal relationship between symptom onset and drug initiation, together with the exclusion of infectious etiologies, makes adalimumab the likely culprit. 


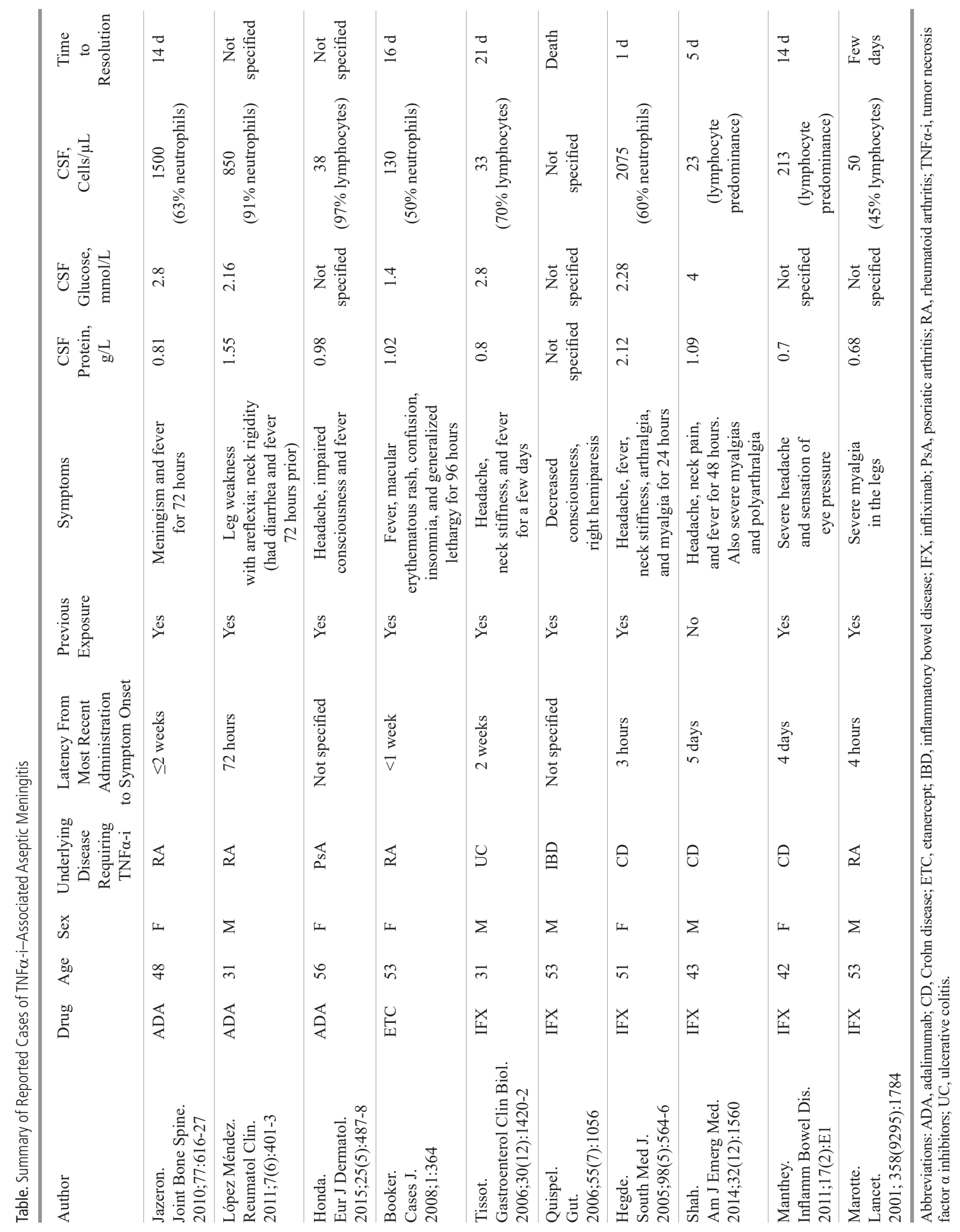


The pathophysiology of TAAM remains unclear. Direct toxic effects appear unlikely, since $\mathrm{TNF} \alpha-\mathrm{i}$ cannot cross the blood-brain barrier. In cases with associated myalgia and arthralgia, a type III hypersensitivity reaction akin to serum sickness mediated by drug autoantibodies has been postulated [6]. We propose that an altered cytokine milieu resulting from peripheral inhibition of $\mathrm{TNF} \alpha$ upregulates proinflammatory pathways in the brain of susceptible individuals, thus leading to TAAM; these pathways may be independent of TNF $\alpha$, as evidenced by the absence of TNF $\alpha$ in CSF in the patient reported by Marotte et al [2].

In conclusion, we report the first case of TAAM in a patient receiving adalimumab for chronic plaque psoriasis. It is important for dermatologists to recognize this rare but potentially serious complication so that non-TNF $\alpha$-i biologics can be administered instead.

\section{Funding}

The authors declare that no funding was received for the present study.

\section{Conflicts of Interest}

The authors declare that they have no conflicts of interest.

\section{References}

1. Sorenson E, Koo J. Evidence-based adverse effects of biologic agents in the treatment of moderate-to-severe psoriasis: Providing clarity to an opaque topic. J Dermatolog Treat. 2015;26(6):493-501.

2. Marotte H, Charrin JE, Miossec P. Infliximab-induced aseptic meningitis. Lancet. 2001;358(9295):1784.

3. Ooi MH, Wong SC, Podin Y, Akin W, del Sel S, Mohan A, Chieng CH, Perera D, Clear D, Wong D, Blake E, Cardosa J, Solomon T. Human enterovirus 71 disease in Sarawak, Malaysia: a prospective clinical, virological, and molecular epidemiological study. Clin Infect Dis. 2007;44(5):646-56.

4. Morís G, Garcia-Monco JC. The challenge of drug-induced aseptic meningitis revisited. JAMA Intern Med. 2014;174(9):1511-2.

5. Honda Y, Otsuka A, Egawa G, Inoue Y, Kuzuya A, Takahashi R, Miyachi Y, Kabashima K. Multiple neurological abnormalities, including pontine hemorrhage, multiple sclerosis and aseptic meningitis, during anti-TNF- $\alpha$ therapy in psoriatic arthritis. Eur J Dermatol. 2015;25(5):487-8.

6. Hegde N, Gayomali C, Rich MW. Infliximab-induced headache and Infliximab-induced meningitis: two ends of the same spectrum? S Med J. 2005;98(5):564-6.

Manuscript received December 5, 2016; accepted for publication February 27, 2017.

\section{Component-Resolved Diagnosis of Dog Allergy}

Basagaña $\mathrm{M}^{1}$, Luengo $\mathrm{O}^{2}$, Labrador $\mathrm{M}^{2}$, Garriga $\mathrm{T}^{3}$, Mattsson $\mathrm{L}^{4}$, Lidholm $\mathrm{J}^{4}$, Cardona $\mathrm{V}^{2}$

${ }^{1}$ Allergy Unit, Hospital Universitari Germans Trias i Pujol, Universitat Autónoma de Barcelona, Badalona, Spain

${ }^{2}$ Allergy Section, Department of Internal Medicine, Hospital Universitari de la Vall d'Hebron, Universitat Autónoma de Barcelona, Barcelona, Spain

${ }^{3}$ Pediatric Allergy Unit, Pediatric Allergy and Pulmonology Department, Hospital Universitari de la Vall d'Hebron, Universitat Autónoma de Barcelona, Barcelona, Spain

${ }^{4}$ Thermo Fisher Scientific, Uppsala, Sweden

J Investig Allergol Clin Immunol 2017; Vol. 27(3): 185-187 doi: 10.18176/jiaci.0150

Key words: Dog allergy. Component-resolved diagnosis.

Palabras clave: Alergia a epitelio de perro. Diagnóstico por componentes.

Dog allergy is a common cause of allergic respiratory symptoms and a worldwide problem that affects $5 \%-10 \%$ of the adult population [1]. The prevalence of sensitization to mammal epithelia (dogs included) seems to be growing. In an epidemiological study carried out in Spain [2], mammal epithelia were the third most common cause of sensitization in rhinitis and asthma, after dust mites and pollens. In the subgroup of rhinitis, the most common offending dander was cat, followed by horse, whereas among patients with asthma, cat dander and dog dander were the most common.

Commercial dander extracts are routinely used for diagnosis of allergy to dog dander, both in vitro and in vivo. The outcome of skin tests depends largely on the quality of the extracts [3]. Sources other than dander, such as saliva and urine, have proven to contain important allergens, which may help to improve the diagnosis of allergy to dog dander $[4,5]$.

Unlike cat allergy, which is almost entirely attributable to sensitization to its major allergen, Fel d 1, the sensitization profile for dog allergy is more heterogeneous [6].

To date, 6 dog allergens have been described. Can $\mathrm{f} 1$, Can $\mathrm{f} 2$, Can $\mathrm{f} 4$, and Can $\mathrm{f} 6$ belong to the lipocalin protein family, show weak but significant similarity and crossreactivity to homologous proteins in other animal species, and are present in both dander and saliva. Can $\mathrm{f} 3$, a dog albumin that has been relatively well preserved throughout the evolution of the species, causes extensive cross-reactivity with other animal albumins. The protein prostatic kallikrein Can $\mathrm{f}$ 5 , which is derived from dog urine [7] and cross-reacts with human seminal fluid [7], was identified in 2009.

The aim of this study was to use component-resolved diagnosis to evaluate the sensitization profile of dog-allergic patients in order to establish the relevance of each of these allergens in our population.

Sera from dog-allergic patients were tested for $\operatorname{sigE}$ to Can $\mathrm{f} 1$, Can $\mathrm{f} 2$, and Can $\mathrm{f} 3$ using the ImmunoCAP ISAC 
Table. Dog Allergen Values

\begin{tabular}{|c|c|c|c|c|c|c|c|}
\hline & Mean & Median & SD & Minimum & Maximum & $>0.33 \mathrm{ISU}$ & $>0.35 \mathrm{kU} / \mathrm{L}$ \\
\hline Can $\mathrm{f} 1$ & 5.0 & 0.0 & 12.0 & 0.0 & 71.3 & $29(41 \%)$ & \\
\hline Can $\mathrm{f} 2$ & 2.7 & 0.0 & 9.6 & 0.0 & 68.6 & $10(14 \%)$ & \\
\hline Can $\mathrm{f} 3$ & 2.2 & 0.0 & 8.3 & 0.0 & 61 & $14(20 \%)$ & \\
\hline Can $\mathrm{f} 5$ & 8.0 & 1.0 & 21.4 & 0.0 & 100 & & $47(67 \%)$ \\
\hline Dog dander & 14.3 & 3.3 & 23.8 & 0.35 & 100 & & $70(100 \%)$ \\
\hline Total IgE & 408.1 & 234.0 & 418.8 & 30.8 & 1810.0 & & \\
\hline
\end{tabular}

platform and for sIgE to rCan $\mathrm{f} 5$ using ImmunoCAP (Thermo Fisher Scientific). All patients had a clinical diagnosis of dog allergy with respiratory symptoms (asthma and/or rhinoconjunctivitis), a positive skin prick test response (dog dander [50 $000 \mathrm{DBU} / \mathrm{mL}$ ], Bial-Aristegui), and positive specific IgE to dog dander extract.

The study population included 70 patients (38 females and 32 males) aged between 10 and 61 years. The symptoms reported were rhinoconjunctivitis and asthma in 39 patients (55.7\%), rhinoconjunctivitis in $29(41.4 \%)$, and respiratory symptoms plus acute urticaria upon in contact with dog dander in 2.

Of the sera tested, 47 (67\%) showed IgE reactivity to Can f 5. Can f 1, Can f 2, and Can f 3 proved to be minor allergens among the study patients, binding sIgE antibody in only $29(41.4 \%), 10(14.3 \%)$, and $14(20 \%)$, respectively. Moreover, 27 out of 70 sera $(39 \%)$ did not react to any of these 3 allergens. Twenty-six (37\%) of the 70 sera reacted to rCan f 5 alone. Only 4 of the 70 sera tested lacked IgE reactivity to all 4 dog allergens tested. Values for dog allergens are summarized in the Table.

In the light of these findings, we can conclude that Can $\mathrm{f} 5$ was a major dog allergen in the study population and, considering that $37 \%$ of our patients are monosensitized to Can $\mathrm{f} 5$, its inclusion in panels for component-resolved diagnosis clearly improves their sensitivity. Can f 1 , Can f 2 , and Can $\mathrm{f} 3$ were minor dog allergens in the study population.

Our findings reaffirm the hypothesis proposed by our research group some years before identification of Can $\mathrm{f} 5$, namely, that the poor response to immunotherapy in dogallergic patients could be caused by unknown allergens not included in the immunotherapy extracts. [8-10]

Given the high variability between commercial dog extracts with respect to their allergen contents and the fact that Can $\mathrm{f} 5$ is poorly represented, it does not seem appropriate to indicate specific immunotherapy with dog extract in patients monosensitized to Can f 5 until extracts contain adequate amounts of this major allergen.

\section{Funding}

The authors declare that no funding was received for the present study.

\section{Conflicts of Interest}

The authors declare that they have no conflicts of interest.

\section{References}

1. Gergen PJ. Total IgE levels and asthma prevalence in the US population: results from the National Health and Nutrition Examination Survey 2005-2006. J Allergy Clin Immunol. 2009; 124:447-53.

2. Navarro A, Colás C, Antón E, Conde J, Dávila I, Dordal MT, Fernández-Parre B, Ibáñez MD, Lluch-Bernal M, Matheu $V_{\text {, }}$ Montoro J, Rondón C, Sánchez MC, ValeroA; Rhinoconjunctivitis Committee of the SEAIC. Epidemiology of allergic rhinitis in allergy consultations in Spain: Alergológica-2005. J Investig Allergol Clin Immunol. 2009;19 Suppl 2:7-13.

3. Curin $M$, Reininger $R$, Swoboda I, Focke $M$, Valenta $R$, Spitzauer $S$. Skin prick test extracts for dog allergy diagnosis show considerable variations regarding the content of major and minor dog allergens. Int Arch Allergy Immunol. 2011;154:258-63.

4. Polovic N, Waden K, Binnmyr J, Hamsten C, Gronneberg R, Palmberg C, Milcic-Matic N, Bergman T, Gronlund H, van Hage M. Dog saliva - an important source of dog allergens. Allergy. 2013;68(5):585-92.

5. Mattsson L, Lundgren $T$, Everberg $H$, Larsson $H$, Lidholm J. Prostatic kallikrein: a new major dog allergen. J Allergy Clin Immunol. 2009;123:362-8.

6. Nilsson $\mathrm{OB}$, Van Hage M, Grönlund H. Mammalian-derived respiratory allergens - Implications for diagnosis and therapy of individuals allergic to furry animals. Methods. 2014;66:8695

7. Basagaña M, Bartolome B, Pastor-Vargas C, Mattsson L, Lidholm J, Labrador-Horrillo M. Involvement of Can $f$ in a Case of Human Seminal Plasma Allergy. Int Arch Allergy Immunol. 2012;159(2):143-6

8. Basagaña $M$, Bartolomé $B$, Pastor C, Torres $F$, Alonso $R$, Vivanco F, Cisteró-Bahíma A. Allergy to human seminal fluid: Cross-reactivity with dog dander.. J Allergy Clin Immunol. 2008; 121(1):233-9.

9. Hedlin G, Graff-Lonnevig V, Heilborn H, Lilja G, Norrlind K, Pegelow K, Sundin B, Lowenstein H. Immunotherapy with cat- 
and dog-dander extracts. V. Effects of 3 years of treatment. J Allergy Clin Immunol. 1991;87(5):955-64.

10. Haugaard L, Dahl R. Immunotherapy in patients allergic to cat and dog dander. I. Clinical results. Allergy. 1992;47(3):24954.

Manuscript received February 21, 2017; accepted for publication March 6, 2017.

\author{
Maria Basagaña Torrentó \\ Allergy Unit \\ Hospital Universitari Germans Trias i Pujol \\ Crta/ Del Canyet, s/n \\ 08916 Badalona, Spain \\ E-mail: maria.basagana.torrento@gmail.com
}

\section{Identification of Novel JAK3 Mutations by Whole- Exome Sequencing in a Korean Boy With Severe Combined Immunodeficiency}

Shim $\mathrm{YJ}^{1}$, Ha JS ${ }^{2}$

${ }^{1}$ Department of Pediatrics, Institute for Cancer Research, Keimyung University School of Medicine and Dongsan Medical Center, Daegu, Korea

${ }^{2}$ Department of Laboratory Medicine, Keimyung University School of Medicine and Dongsan Medical Center, Daegu, Korea

J Investig Allergol Clin Immunol 2017; Vol. 27(3): 187-189 doi: 10.18176/jiaci.0151

Key words: Exome sequencing. Next generation sequencing. Janus kinase 3. Primary immunodeficiency. Severe combined immunodeficiency.

Palabras clave: Secuenciación del exoma. Secuenciación de nueva generación. Janus quinasa 3. Inmunodeficiencia primaria. Inmunodeficiencia combinada severa.

Screening of newborns for severe combined immunodeficiency (SCID) has not yet been implemented in Korea. Furthermore, in most Korean medical centers, genetic testing for SCID based on conventional methods is not possible, except for X-linked SCID. Here, we report the first case of a patient in whom Janus kinase 3 (JAK3)-deficient SCID with novel mutations was diagnosed using whole exome sequencing.

A 4-month-old boy was admitted with dyspnea, mild fever, tachypnea, and chest retraction. Oral intake had been poor for some time, and the patient had failed to thrive. His older brother was healthy, and his family history was unremarkable. At admission, contrast-enhanced computed tomography of the chest revealed interstitial pneumonia (alveolitis) suggestive of Pneumocystis jiroveci pneumonia or atypical viral pneumonia. The patient was treated with intravenous trimethoprim/ sulfamethoxazole, methylprednisolone, and immunoglobulin.

The lymphocyte subset panel showed that $\mathrm{CD}^{+} \mathrm{T}$-cell, $\mathrm{CD}^{+}$helper T-cell, CD8 ${ }^{+}$cytotoxic T-cell, and CD16/56 ${ }^{+}$ NK cell percentages were all low (Table). The CD19 ${ }^{+} \mathrm{B}$-cell percentage was elevated, although $\operatorname{IgG}, \mathrm{A}$, and $\mathrm{M}$ levels had decreased to $14.5 \mathrm{mg} / \mathrm{dL}$ (reference range, $700-1600 \mathrm{mg} / \mathrm{dL}$ ), $23.9 \mathrm{mg} / \mathrm{dL}$ (reference range, 70-400 mg/dL), and $16.8 \mathrm{mg} / \mathrm{dL}$ (reference range, $40-230 \mathrm{mg} / \mathrm{dL}$ ), respectively. The test for infection with human immunodeficiency virus was negative. The absolute neutrophil count, lymphocyte count, and complement levels were all within the normal range. The laboratory results suggested $\mathrm{SCID}(\mathrm{T} \pm \mathrm{B}+\mathrm{NK}-)$.

Whole exome sequencing was performed to identify the causative genetic defect underlying the suspected diagnosis of SCID. Peripheral blood was collected from the patient and his family members (father, mother, and older brother). Genomic DNA was extracted and measured, as described in our previous study, using the Wizard DNA purification Kit (Promega Corporation) and the PicoGreen method (Invitrogen) 
Table. Repetitive Lymphocyte Subset Results Before and After UCBT in a Boy With JAK3-Deficient Severe Combined Immunodeficiency

\begin{tabular}{|c|c|c|c|c|c|c|c|}
\hline & \multicolumn{3}{|c|}{ Before UCBT } & \multicolumn{3}{|c|}{ After UCBT } & \multirow{2}{*}{$\begin{array}{c}\text { Reference } \\
\text { Range }\end{array}$} \\
\hline & First & Second & Third & First & Second & Third & \\
\hline CD45 (panWBC), $\%$ & 100 & 100 & 100 & 100 & 100 & 100 & $>50$ \\
\hline CD3 (T-cell), \% & 32.08 & 11.7 & 42.86 & 63.63 & 75.63 & 67.87 & $55-74$ \\
\hline CD4 (helper), $\%$ & 1.27 & 0.54 & 4.07 & 17.61 & 44.51 & 24.71 & $33-57$ \\
\hline CD8 (cytotoxic), $\%$ & 30.38 & 9.99 & 36.15 & 39.80 & 27.23 & 39.34 & $18-32$ \\
\hline $\mathrm{CD} 4 / \mathrm{CD} 8$ ratio & 0.0 & 0.1 & 0.1 & 0.4 & 1.6 & 0.6 & $1.3-2.0$ \\
\hline CD19 (B-cell), \% & 65.95 & 88.37 & 49.99 & 0.29 & 1.14 & 8.72 & $15-35$ \\
\hline CD16/56 (NK-cell), \% & 0.24 & 0.11 & 3.11 & 33.22 & 19.51 & 17.73 & $5-15$ \\
\hline
\end{tabular}

Abbreviation: UCBT, umbilical cord blood transplantation; WBC, white blood cell.

based on Victor3 fluorometry [1]. Whole exome sequencing was performed as described in our previous study using the SureSelect Human All Exon V4 kit (Agilent Technologies) and HiSeq2000 (Illumina) [1]. The reads generated were mapped against UCSC hg19 using a mapping program (Burrow-Wheeler Alignment tool). The PCR duplicates were removed using the PICARD tool, and single-nucleotide polymorphisms (SNPs) and insertions-deletions were detected using SAMTOOLS [1]. The specific list of genes implicated in primary immunodeficiency (PID) was based on Picard et al [2].

The number of total reads was 99543 038, and the average throughput depth of target regions was 196.4. The mean number of observed variants was 67170 (number of coding SNPs, 19 195; synonymous SNPs, 10 106; nonsynonymous SNPs, 8634; indels, 6234; and coding indels, 442). The list of genes implicated in PID [2] was scanned, and 2 novel JAK3 mutations were found (c.503T $>$ A [p.L168*] and c.441delT [p.Ser147Argfs*39]).

The genomic regions were amplified using an automatic genetic analyzer (Dr. MAX DNA Polymerase kit, MG Taq-HF DNA Polymerase, MGMED Co, Seoul, Korea) and validated by Sanger sequencing using both forward and reverse primers as follows: primers for c.503T $>$ A, TATCCTTGACCTGCCAGTCC (forward) and GGGTCATAGGAACACCCTGA (reverse); primers for c.441delT, CAGGCACACACAGACTCTCA (forward) and GCGGATAACAATTTCACACAGGGCCTCAGTCTCA AGGAGCAG (reverse). The former mutation (c.503T $>$ A) was inherited from the patient's mother, and the latter (c.441delT) from his father. The patient's older brother did not carry either mutation.

For evaluation of RNA expression, RNA was extracted from the patient and his family members using a Paxgene Blood RNA tube (PreAnalytiX) according to the manufacturer's guidelines. The relative $J A K 3$ RNA expression was estimated using a Taqman Realtime PCR analysis with a PCR Probe (Hs00169663 m1). The patient's expression of RNA in JAK3 was markedly lower than that of his older brother, the healthy control.

Following the diagnosis of $J A K 3$-deficient SCID by genetic testing, the patient underwent hematopoietic stem cell transplantation (HSCT). By this stage, he had developed respiratory syncytial virus (RSV) infection, which was refractory to immunoglobulin and antiviral therapy. The HLA types of the patient and his older brother were not identical. The patient's mother was HLA-typed to evaluate the possibility of maternal lymphocyte engraftment, but the patient's HLA type was haploidentical to that of his mother. HSCT using umbilical cord blood was performed based on reduced intensity conditioning with fludarabine and melphalan when the patient was 8 months of age. Prophylaxis of graft-versushost disease (GVHD) was administered using ciclosporin and mycophenolate mofetil. The variable number of tandem repeats from DNA obtained from $\mathrm{CD}^{+} \mathrm{T}$ cells showed complete donor chimerism, and lymphocyte subset results were improved after HSCT (Table). However, the patient experienced corticosteroid-refractory, grade IV acute GVHD (skin 4, liver 0, gut 4), which was treated with infliximab and methotrexate. The previous RSV infection was reactivated following immunosuppressive therapy, and the patient died at 18 months of age.

While mutations of the $\gamma$ chain of the interleukin-2 receptor are the most common cause of SCID (X-linked SCID), mutations in the associated downstream signalling enzyme $J A K 3$ also result in $\mathrm{T}-\mathrm{B}+\mathrm{NK}-\mathrm{SCID}$ [3]. The 2 forms of SCID are associated with similar phenotypes, which include recurrent or atypical severe respiratory infections, intractable diarrhea, and failure to thrive. Patients with SCID due to $J A K 3$ deficiency or X-linked SCID may exhibit diverse clinical manifestations and heterogeneous phenotypes, such as $\mathrm{T} \pm \mathrm{B}+\mathrm{NK}-\mathrm{SCID}$, even within a single family $[4,5]$.

The main prognostic factors for positive transplant outcome and survival in SCID patients are early diagnosis of SCID, HSCT before 3.5 months of age, and the absence of pretransplant infection [6]. In addition, grade IV GVHD and progressive infections contribute to high mortality following umbilical cord blood transplantation in PID [7].

Whole exome sequencing is not a universally accepted method for diagnosis of SCID. Dried blood spot-based newborn screening by quantifying T-cell receptor excision circles is an established method for SCID in developed countries [8]. However, dried blood spot screening for SCID 
is not yet possible in many developing countries, including Korea. Furthermore, the specific genetic defect underlying PID has not been identified in Korea, except in X-linked SCID. Early diagnosis of SCID is very important for improvement of the survival rate after stem cell transplant considering the aforementioned prognostic factors, age, and absence of pretransplant infection. Therefore, we performed whole exome sequencing. In polygenic diseases with several candidate genes, this approach may be used for confirmation of disease, planning treatment, and genetic counselling for the family. To the best of our knowledge, this is the first case of JAK3deficient SCID in Korea. When other diagnostic methods are not available, we recommend using whole exome sequencing to test for PID in patients with atypical infections and failure to thrive as early as possible.

\section{Funding}

This research was supported by a Keimyung University Research Grant for 2015.

\section{Conflicts of Interest}

The authors declare that they have no conflicts of interest.

\section{References}

1. Shim YJ, Kim JE, Hwang SK, Choi BS, Choi BH, Cho EM, Jang KM, Ko CW. Identification of candidate gene variants in Korean MODY families by whole-exome sequencing. Horm Res Paediatr. 2015;83:242-51.

2. Picard C, Al-Herz W, Bousfiha A, Casanova JL, Chatila T, Conley ME, Cunningham-Rundles C, Etzioni A, Holland SM, Klein C, Nonoyama S, Ochs HD, Oksenhendler E, Puck JM, Sullivan KE, Tang ML, Franco JL, Gaspar HB. Primary immunodeficiency diseases: an update on the classification from the International Union of Immunological Societies Expert Committee for Primary Immunodeficiency 2015. J Clin Immunol. 2015;35:696-726.

3. Roberts JL, Lengi A, Brown SM, Chen M, Zhou YJ, O'Shea JJ, Buckley RH. Janus kinase 3 (JAK3) deficiency: clinical, immunologic, and molecular analyses of 10 patients and outcomes of stem cell transplantation. Blood. 2004;103:200918.

4. Frucht DM, Gadina M, Jagadeesh GJ, Aksentijevich I, Takada K, Bleesing JJ, Nelson J, Muul LM, Perham G, Morgan G, Gerritsen EJ, Schumacher RF, Mella P, Veys PA, Fleisher TA, Kaminski ER, Notarangelo LD, O'Shea JJ, Candotti F. Unexpected and variable phenotypes in a family with JAK3 deficiency. Genes Immun. 2001;2:422-32.

5. Wada T, Toma T, Yasui M, Inoue M, Kawa K, Imai K, Morio T, Yachie A. Different clinical phenotypes in 2 siblings with $X$-linked severe combined immunodeficiency. J Investig Allergol Clin Immunol. 2016;26:63-5.

6. Pai SY, Logan BR, Griffith LM, Buckley RH, Parrott RE, Dvorak CC, Kapoor N, Hanson IC, Filipovich AH, Jyonouchi S, Sullivan KE, Small TN, Burroughs L, Skoda-Smith S, Haight AE, Grizzle A, Pulsipher MA, Chan KW, Fuleihan RL, Haddad E, Loechelt B, Aquino VM, Gillio A, Davis J, Knutsen A, Smith AR, Moore TB,
Schroeder ML, Goldman FD, Connelly JA, Porteus MH, Xiang Q, Shearer WT, Fleisher TA, Kohn DB, Puck JM, Notarangelo LD, Cowan MJ, O'Reilly RJ. Transplantation outcomes for severe combined immunodeficiency, 2000-2009. N Engl J Med. 2014;371:434-46.

7. Díaz de Heredia C, Ortega JJ, Díaz MA, Olivé T, Badell I, González-Vicent M, Sánchez de Toledo J. Unrelated cord blood transplantation for severe combined immunodeficiency and other primary immunodeficiencies. Bone Marrow Transplant. 2008;41:627-33.

8. van der Spek J, Groenwold RH, van der Burg M, van Montfrans JM. TREC based newborn screening for severe combined immunodeficiency disease: a systematic review. J Clin Immunol. 2015;35:416-30.

Manuscript received October 21, 2016; accepted for publication March 9, 2017.

Ye Jee Shim Keimyung University School of Medicine and Dongsan Medical Center Dalseong-ro 56 (Dongsan-dong 194), Jung-gu, Daegu 41931 (700-712), Korea E-mail: yejeeshim@dsmc.or.kr 


\section{Pulmonary Embolism After Ceftriaxone-Induced Anaphylaxis}

De Pasquale TMA ${ }^{1}$, Buonomo A ${ }^{2}$, Di Gennaro L ${ }^{3}$, Pucci $\mathrm{S}^{1}$

${ }^{1}$ Allergy Unit, Ospedale di Civitanova Marche, Civitanova Marche, Italy

${ }^{2}$ Allergy Unit, Fondazione Policlinico Gemelli, Rome, Italy

${ }^{3}$ Thrombotic and Haemorrhagic Disorder Unit, Fondazione

Policlinico Gemelli, Rome, Italy

J Investig Allergol Clin Immunol 2017; Vol. 27(3): 190-191 doi: $10.18176 /$ jiaci.0152

Key words: Pulmonary embolism. Ceftriaxone hypersensitivity. Anaphylaxis.

Palabras clave: Embolismo pulmonar. Hipersensibilidad a ceftriaxone. Anafilaxia.

In 1980, Smith et al [1] reported activation of the coagulation process in 2 patients during hymenoptera sting challenge but did not explain the underlying pathogenic mechanism. The reduction in factors V and VIII and fibrinogen indicated a concomitant thrombotic process. The occurrence of thromboembolic events leading to acute coronary syndrome or cerebral ischemic stroke has been described during hymenoptera venom-induced anaphylaxis and in patients with no other risk for thromboembolism $[2,3]$.

We report a case of pulmonary embolism (PE) following ceftriaxone-induced anaphylaxis. A 77-year-old man with clinical signs of right saphenous vein thrombophlebitis and fever had been prescribed intramuscular ceftriaxone by his attending physician. He had no known prothrombotic risk factors for PE or deep vein thrombosis (DVT) such as personal or familiar history of venous thromboembolism, active malignancy, recent surgery or trauma, immobilization, inherited thrombophilia, obesity, and cardiac and/or respiratory failure.

Thirty minutes following the second injection of $1 \mathrm{~g}$ of ceftriaxone, he developed general itching, dizziness, abdominal pain, diarrhea, tachypnea, and chest pain. Two hours later, he was taken to the emergency department of the local hospital, where he was treated with intravenous chlorphenamine $10 \mathrm{mg}$ and betamethasone $4 \mathrm{mg}$.

Blood pressure and pulse rate were within the normal range at admission. Blood gas analysis revealed hypocapnia $(24 \mathrm{mmHg})$ and hypoxemia $(65 \mathrm{mmHg})$. A chest computed tomography scan with iodinated contrast media showed obstruction of a segmental branch of the right pulmonary artery. Electrocardiography and echocardiography did not reveal myocardial involvement. Ultrasonography confirmed the diagnosis of right saphenous vein thrombosis, but no signs of deep vein involvement were found. D-dimer level was $6732 \mathrm{ng} / \mathrm{mL}$; fibrinogen was within normal ranges.

The patient received sodium enoxaparin and was discharged with oral acenocoumarol 10 days later. No signs of thromboembolism were evident.
Three months later, he underwent allergy testing with $\beta$-lactam agents according to published guidelines [5]. Skin prick and intradermal tests with penicilloyl-polylysine, minor determinant mixture, benzylpenicillin, ampicillin, and amoxicillin were negative while intradermal testing with ceftriaxone at a concentration of $0.2 \mathrm{mg} / \mathrm{mL}$ induced a strongly positive wheal and flare reaction $(8.5 \mathrm{~mm}$ and $15.5 \mathrm{~mm})$.

At the end of the allergy workup, the patient underwent a challenge test with amoxicillin and tolerated increasing doses up to a final dose of $1 \mathrm{~g}$ on 1 day. These data were consistent with the diagnosis of IgE-mediated allergy to ceftriaxone.

Superficial thrombophlebitis is more frequent in patients with varicose veins and frequently involves the great saphenous system. It is usually a benign condition, with concomitant deep vein thrombosis (DVT) in $6 \%-53 \%$ of cases. The risk of PE can be as high as $18 \%$, especially when DVT is present [6]. A recent review of 11 studies (2484 patients) found a weighted mean prevalence of $6.9 \%$ for PE in patients with superficial vein thrombosis, especially in those with known risk factors [7].

The reduction in levels of fibrinogen and factors $\mathrm{V}$ and VIII during hymenoptera sting challenge reported by Smith et al [1] were strongly suggestive of a concomitant thrombotic process. Other authors have reported cases of disseminated intravascular coagulation during hymenoptera sting-induced anaphylaxis $[8,9]$. In fact, platelet-activating factor is released by mast cells during anaphylaxis, and high levels of plateletactivating factor (PAF) correlate strongly with the severity of anaphylaxis [10]. PAF may lead to platelet activation and consequent consumption of fibrinogen and coagulation factors.

However, in the case we report, the fact that no low platelet count or low fibrinogen level was recorded enabled us to rule out disseminated intravascular coagulation. The risk of PE during superficial thrombophlebitis is low in the absence of DVT and/or other prothrombotic factors. While we are not able to determine whether PE was induced by platelet or coagulation activation, the anaphylactic event may have played a pivotal role. Activated platelets are able to bind fibrinogen, and this may have led to the formation of a thrombus and consequent PE.

PE and other thrombotic events should be considered a complication in patients with non-insect sting anaphylaxis.

\section{Funding}

The authors declare that no funding was received for the present study.

\section{Conflicts of Interest}

The authors declare that they have no conflicts of interest.

\section{References}

1. Smith PL, Kagey-Sobotka A, Bleecker ER, Traystman R, Kaplan $A P$, Gralnick $H$, Valentine MD, Permutt $S$, Lichtenstein LM. Physiologic manifestations of human anaphylaxis. I Clin Invest. 1980;66:1072-80. 
2. Kasim S, AbuBakar R, McFadden E. Anaphylaxis from wasp stings inducing coronary thrombus. Case Rep Cardiol. 2012;2012:701753.

3. Johnson JA, Frith JA, Casselman J, Saad A, Tcheurekdjian H, Hostoffer R. Thromboembolic stroke: a sequela of Hymenoptera venom-induced anaphylaxis. Ann Allergy Asthma Immunol. 2016;116:262-4.

4. Worm M, Moneret-Vautrin A, Scherer K, Lang R, FernandezRivas M, Cardona V, Kowalski ML, Jutel M, PoziomkowskaGesicka I, Papadopoulos NG, Beyer K, Mustakov T, Christoff G, Bilò MB, Muraro A, Hourihane JO, Grabenhenrich LB. First European data from the network of severe allergic reactions (NORA). Allergy. 2014;39:1397-404.

5. Mirakian R, Leech SC, Krishna MT, Richter AG, Huber PA, Farooque S, Khan N, Pirmohamed M, Clark AT, Nasser SM; Standards of Care Committee of the British Society for Allergy and Clinical Immunology. Management of allergy to penicillins and other betalactams. Clin Exp Allergy. 2015;45:300-27.

6. Nasr H, Scriven JM. Superficial thrombophlebitis (superficial venous thrombosis). BMJ. 2015;350:h2039.

7. Di Minno MND, Ambrosino P, Ambrosini F, Tremoli E, Di Minno G, Dentali F. Prevalence of deep vein thrombosis and pulmonary embolism in patients with superficial vein thrombosis: a systematic review and meta-analysis. J Thromb Haemost. 2016;14:964-72.

8. George P, Pawar B, Calton N, Mathew P.Wasp sting: an unusual fatal outcome. Saudi J Kidney Dis Transplant. 2008;19:96972.

9. Gawklik R, Rymarczyk B, Rogala B. A rare case of intravascular coagulation after honey bee sting. J Invest Allergol Clin Immunol. 2004;14:250-2.

10. Vadas P, Gold M, Perelman B, Liss GM, Lack G, Blyth T, Simons FER, Simons KJ. Cass D, Yeung J. Platelet-activating factor, PAF acetylhydrolase, and severe anaphylaxis. N Engl J Med. 2008;358:28-35.

Manuscript received December 4, 2016; accepted for publication March 13, 2017

\author{
Alessandro Buonomo \\ Allergy Unit, Fondazione Policlinico Gemelli \\ Largo Gemelli, 8 \\ 00168 Rome \\ Italy \\ E-mail: alessandro.buonomo@policlinicogemelli.it
}

\section{Stevens-Johnson Syndrome/Toxic Epidermal Necrolysis Overlap Induced by Fexofenadine}

Teo SL ${ }^{1}$, Santosa $\mathrm{A}^{2,3}$, Bigliardi $\mathrm{PL}^{2,4}$

${ }^{1}$ National University Hospital, Singapore

${ }^{2}$ Division of Rheumatology, University Medicine Cluster, National University Health System, Singapore

${ }^{3}$ Department of Medicine, Yong Loo Lin School of Medicine, National University of Singapore, Singapore

${ }^{4}$ Experimental Dermatology Group, Institute of Medical Biology, A *STAR, Singapore

J Investig Allergol Clin Immunol 2017; Vol. 27(3): 191-193 doi: $10.18176 /$ jiaci.0158

Key words: Stevens-Johnson syndrome. Toxic epidermal necrolysis. Fexofenadine. Telfast-D. Antihistamine. Patch testing.

Palabras clave: Síndrome de Stevens-Johnson. Necrólisis epidérmica tóxica. Fexofenadina. Telfast-D. Antihistamínico. Pruebas epicutáneas.

Stevens-Johnson syndrome and toxic epidermal necrolysis (SJS/TEN) have been well described in the literature as severe cutaneous adverse reactions (SCARs). SJS/TEN can occur after exposure to various drugs, including antibiotics (eg, sulfonamides, aminopenicillins, cephalosporins, and quinolones), antiepileptics, sulfa drugs, and nonsteroidal anti-inflammatory drugs [1,2]. The purpose of this report is to highlight a case of SJS/TEN overlap secondary to a commonly used medication, fexofenadine-pseudoephedrine (Telfast-D). To our knowledge, this is the first case of SJS/TEN secondary to an antihistamine reported in the literature.

A middle-aged woman with a past medical history of allergic rhinitis and no known drug allergies went to her general practitioner (GP) with a 2-day history of left red eye, rhinitis, and throatache and was prescribed a 5-day course of oral amoxicillin-clavulanic acid $625 \mathrm{mg} 3$ times a day and fusidic acid ointment for her eye. Despite this treatment, the patient's symptoms worsened with fever and dry cough and she self-medicated with paracetamol and ibuprofen.

On day 6, her GP added fexofenadine-pseudoephedrine (Telfast-D, 1 tablet twice daily) to the medication. One day later, after 2 doses of fexofenadine-pseudoephedrine, the patient noticed mild lip swelling. Her other symptoms persisted, and a newly consulted ENT specialist diagnosed sinusitis and changed the antibiotic to clarithromycin $500 \mathrm{mg}$ twice daily. The treatment with fexofenadinepseudoephedrine was continued, and the patient took a further 2 doses.

On day 8, the patient developed more swelling and blisters on her lips and was treated in the emergency department with intravenous hydrocortisone, oral promethazine, and cetirizine-pseudoephedrine. The next day, she was admitted to hospital with high fever $\left(39.5^{\circ} \mathrm{C}\right)$ and developed erythematous nonblanchable, dusky target lesions over the face, trunk, and limbs that affected $20 \%$ of her body surface. Blistering with a 
positive Nikolsky sign was recorded in $<1 \%$ of her skin. She also had bilateral conjunctivitis, hemorrhagic cheilitis, and buccal mucosal erosions.

The patient was treated as for SJS/TEN overlap with topical corticosteroids, cetirizine, and cyclosporine $1.5 \mathrm{mg} / \mathrm{kg}$ twice daily. A skin biopsy from her right forearm revealed full-thickness epidermal necrosis with epidermal apoptosis. Several tests were performed to exclude parainfectious erythema exsudativum multiforme major (EEM major), although these yielded negative results. The tests included blood tests and pharyngeal swabs for infectious diseases such as Epstein-Barr virus, cytomegalovirus, human immunodeficiency virus, hepatitis, human herpesvirus, Mycoplasma pneumoniae, and others. The patient eventually recovered, with full re-epithelialization of her skin after 50 days. The final diagnosis was SJS/TEN secondary to drugs or parainfectious EEM major.

The patient was referred to the allergy clinic 10 weeks later for further elucidation of the etiology. She reported having taken amoxicillin-clavulanic acid, paracetamol, ibuprofen, and other antihistamines such as loratadine-pseudoephedrine (Clarinase) without problems prior to the index admission. She had never taken fexofenadine-pseudoephedrine or clarithromycin before. After admission, she had continued taking paracetamol without problems. The allergy team performed skin tests with immediate and delayed readings using the drugs identified to be possible culprits based on the model of Naranjo et al [3] and the algorithm of drug causality for epidermal necrolysis (ALDEN) model described by Sassolas et al [4]. Skin testing (prick, intradermal, and patch) was performed on healthy skin on the upper arm with penicillin-G, amoxicillin-clavulanic acid, cefazolin, and ceftriaxone. Clarithromycin, fexofenadine-pseudoephedrine, and ibuprofen were only available as oral formulations and were therefore only used in the prick and patch tests. The patch tests were performed in duplicate with application of the drug directly onto the filter paper of IQ chambers from the Chemotechnique series (as-is patch test) or by mixing the drugs 1:1 in white soft paraffin before addition to the patch test chamber.

As expected, the immediate readings of the prick and intradermal tests were negative. However, at the reading 96 hours after application of the drugs, the patch test was clearly positive for fexofenadine-pseudoephedrine, with localized pruritus, and erythema and infiltration of about 8 $\mathrm{mm}$ (Figure). The results of all other patch tests remained negative.

The patch test on her back was repeated to confirm this unexpected finding, along with further tests to determine which component of Telfast-D - fexofenadine or pseudoephedrinewas the cause of the reaction. The drugs tested were fexofenadine (Telfast), fexofenadine-pseudoephedrine (Telfast-D), loratadine-pseudoephedrine (Clarinase), clarithromycin, and ibuprofen. The results at 72 hours confirmed the positive result to fexofenadine and fexofenadinepseudoephedrine. The results of all other patch tests were again negative (Figure). The patient was advised that she could continue to consume antihistamines such as Clarinase

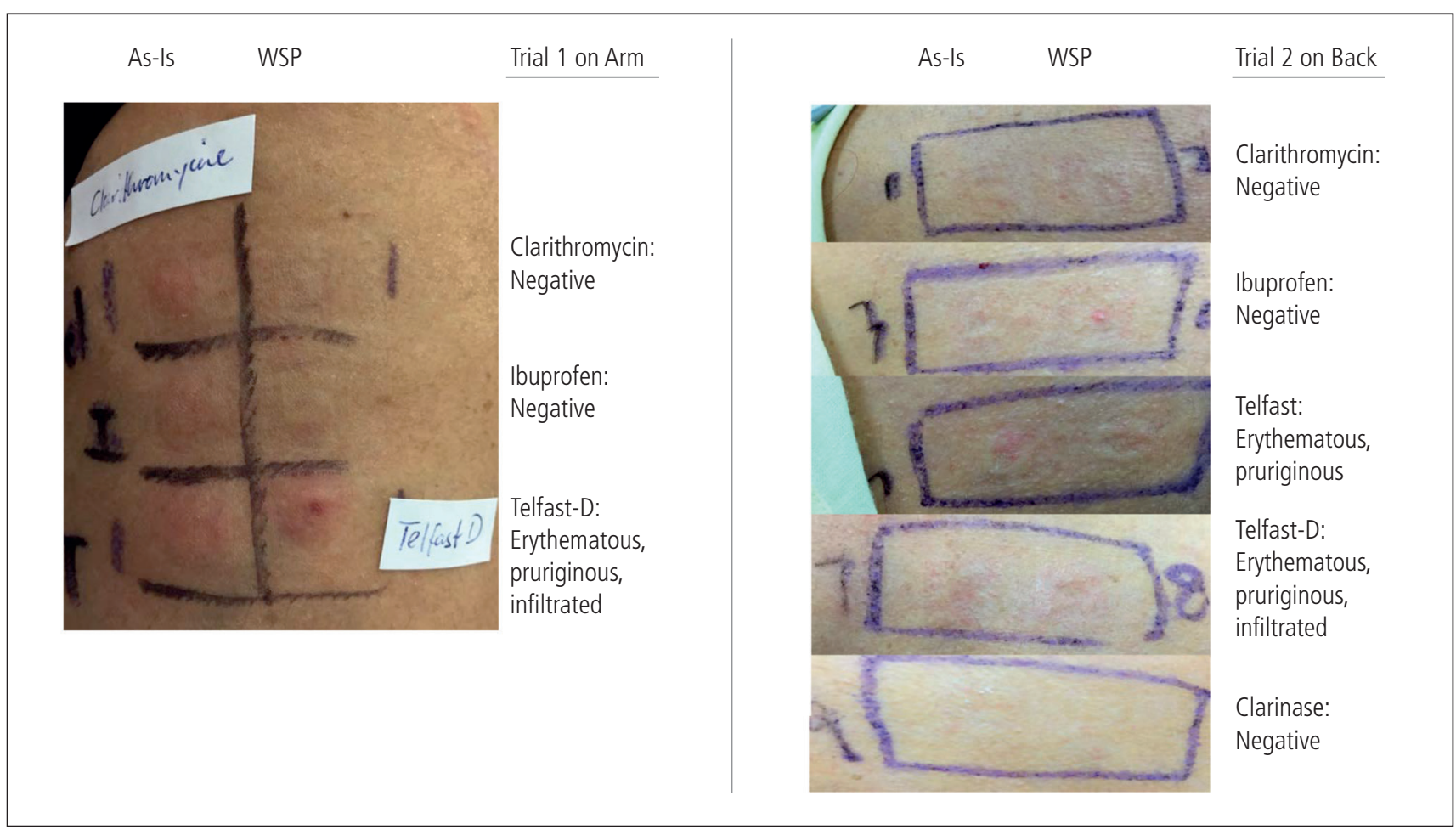

Figure. Patch test results. As-is indicates direct application of drug for patch testing; WSP, drug mixed with white soft paraffin for patch testing. 
and cetirizine but should avoid fexofenadine-containing medications. Given the high likelihood that SJS/TENS was caused by fexofenadine-pseudoephedrine, it was deemed unsafe to propose an oral provocation test with this compound. We proposed oral provocation tests with delayed monitoring to amoxicillin-clavulanic acid, clarithromycin, and ibuprofen to confirm their safety for future consumption. However, the patient refused to perform these additional tests owing to time constraints.

Based on the Naranjo and ALDEN models, the drugs suspected of causing this patient's symptoms were amoxicillin-clavulanic acid, clarithromycin, and ibuprofen $[3,4]$. SJS/TEN has been ascribed to these agents before $[1,2,5,6]$. However, the patient we report did not show any reaction against these agents but instead had a delayedreaction to fexofenadine-pseudoephedrine and fexofenadine alone. The results of tests with loratadine-pseudoephedrine were negative. Based on the patient's history and patch test results, the likely cause for SJS/TEN overlap was the fexofenadine component of Telfast-D.

To our knowledge, this is the first reported case of SJS/TEN overlap involving the antihistamine fexofenadine. Our findings highlight several important points. First, any drug used before the onset of a SCAR should be suspected as the culprit drug. Second, in the management of SCARs, the administration of pharmacotherapy should be limited to drugs that are of vital importance. Our patient was fortunate that she was given cetirizine for her rash rather than fexofenadine-pseudoephedrine. Finally, medications should always be used judiciously. Even over-the-counter antihistamines can cause severe reactions.

\section{Funding}

The authors declare that no funding was received for the present study.

\section{Conflicts of Interest}

The authors declare that they have no conflicts of interest.

\section{References}

1. Schwartz RA, McDonough PH, Lee BW. Toxic Epidermal Necrolysis: Part 1. Introduction, history, classification, clinical features, systemic manifestations, etiology, and immunopathogenesis. J Am Acad Dermatol. 2013;69(2):173.e1-13.

2. Thong BYH. Stevens-Johnson Syndrome/Toxic Epidermal Necrolysis: An Asia-Pacific Perspective. Asia Pac Allergy. 2013; 3(4):215-23.

3. Naranjo CA, Busto U, Sellers EM, Sandor P, Ruiz I, Roberts EA, Janecek E, Domecq C, Greenblatt DJ. A method for estimating the probability of adverse drug reactions. Clin Pharmacol Ther. 1981;30(2):23-45.

4. Sassolas B, Haddad C, Mockenhaupt M, Dunant A, Liss Y, Bork K, Haustein UF, Vieluf D, Roujeau JC, Le Louet H. ALDEN, an algorithm for assessment of drug causality in Stevens-Johnson Syndrome and Toxic Epidermal Necrolysis: Comparison with case-control analysis. Clin Pharm. 2010;88:60-8
5. Khaldi N, Miras Alain, Gromb S. Toxic Epidermal Necrolysis and Clarithromycin. Can J Clin Pharmacol. 2005;12(3):e2648.

6. Mockenhaupt M, Kelly JP, Kaufman D, Stern RS. The risk of Stevens-Johnson syndrome and toxic epidermal necrolysis associated with nonsteroidal antiinflammatory drugs: a multinational perspective. J Rheumatol. 2003;30:2234.

- Manuscript received September 16, 2016; accepted for publication March 23, 2017.

Paul Lorenz Bigliardi

5 Lower Kent Ridge Road Singapore 119074

E-mail: paul_bigliardi@nuhs.edu.sg 


\section{Troponin as a Cause of Hypersensitivity to Barnacle}

Rial Prado $\mathrm{MJ}^{1}$, Batolomé $\mathrm{B}^{2}$, Pastor $\mathrm{C}^{3}$, Cuesta $\mathrm{J}^{4}$, Parra $\mathrm{A}^{1}$

${ }^{1}$ Allergy department, Complexo Hospitalario Universitario A Coruña, A Coruña, Spain

${ }^{2} R \& D$ Department, Roxall España, Bilbao, Spain

${ }^{3}$ Immunology Department, Fundación Jiménez-Díaz, Madrid, Spain

${ }^{4}$ Allergy Department, Fundación Jiménez-Díaz Madrid, Spain

J Investig Allergol Clin Immunol 2017; Vol. 27(3): 194-195 doi: 10.18176/jiaci.0159

Key words: Barnacle. Mites. Food allergy. Shellfish. Seafood.

Palabras clave: Percebe. Ácaros. Alergia alimentaria. Crustáceos. Mariscos.

Barnacles (Pollicipes pollicipes), which are cirripede crustaceans of the Scalpellidae family, are distributed universally along temperate water coastlines [1] and widely consumed. Although crustacean food allergy is relatively frequent and well studied [2], barnacle allergy remains relatively unknown, with only 2 references in the indexed literature $[3,4]$.

We present the case of a 25 -year-old woman who experienced anaphylaxis (generalized urticaria, angioedema, and respiratory distress) immediately ( $<30$ minutes) after the ingestion of barnacles at the age of 14 years. Prior to this episode, she had tolerated barnacles without symptoms. Following the advice of her doctor, the patient was on a crustacean shellish-free diet when examined at the clinic, although she ate bivalves and cephalopods (with no allergic symptoms). She also reported a long history of persistent rhinitis and mild intermittent asthma, which were treated with cetirizine and salbutamol, respectively
Skin prick tests were carried out with the following allergen extracts: Dermatophagoides pteronyssinus, Lepidoglyphus destructor, Tyrophagus putrescentiae, Chortoglyphus arcuatus, latex, Alternaria alternata, Aspergillus fumigatus, cat and dog dander, shrimp, Blattella germanica, and pollens from Cupressus arizonica, Betula alba, Phleum pratense, Cynodon dactylon, Parietaria judaica, Plantago lanceolata, Platanus acerifolia, and Olea europaea. Purified Pho d 2 (pollen profilin) and Pru p 3 (peach lipid transfer protein) were also tested. The results were positive (wheal $\geq 3 \mathrm{~mm}$ ) to $D$ pteronyssinus), $L$ destructor, $T$ putrescentiae, Ch arcuatus, shrimp, and $B$ germanica. We also performed prick-by-prick tests with raw and cooked shrimp and barnacle and obtained positive results in all cases.

As the patient had a negative serum specific $\operatorname{IgE}$ value to shrimp (Pandalus borealis) by ImmunoCAP $\left(<0.35 \mathrm{kU}_{\mathrm{A}} / \mathrm{L}\right)$ and also tolerated inhalation of seafood cooking vapors, an oral food challenge with shrimp was performed. The patient tolerated a cumulative amount of 20 shrimps $(160 \mathrm{~g})$ in the allergy unit, as well as velvet crab (Necora puber) and crab (Maia squinado) at home.

Protein extracts from raw and boiled barnacle were prepared by homogenization in phosphate buffer saline, dialyzation, and lyophilization.

Serum specific IgE levels were measured (Enzyme AllergoSorbent test [EAST technique], HYTEC Specific IgE EIA kit, HYCOR Biomedical Ltd) against extracts from raw barnacle $\left(2 \mathrm{kU}_{\mathrm{A}} / \mathrm{L}\right)$ and boiled barnacle $\left(6.8 \mathrm{kU}_{\mathrm{A}} / \mathrm{L}\right)$, raw Penaeus monodon $(1.8 \mathrm{kU} / \mathrm{A})$ and boiled $P$ monodon $\left(2.2 \mathrm{kU}_{\mathrm{A}} / \mathrm{L}\right)$, Periplaneta americana $\left(2.3 \mathrm{kU}_{\mathrm{A}} / \mathrm{L}\right)$, T putrescentiae $\left(>17.5 \mathrm{kU}_{\mathrm{A}} / \mathrm{L}\right), L$ destructor $\left(>17.5 \mathrm{kU}_{\mathrm{A}} / \mathrm{L}\right)$, D pteronyssinus $\left(17.3 \mathrm{kU}_{\mathrm{A}} / \mathrm{L}\right)$, and the purified tropomyosins Pen i $1\left(<0.35 \mathrm{kU}_{\mathrm{A}} / \mathrm{L}\right)$ and Der p $10\left(<0.35 \mathrm{kU}_{\mathrm{A}} / \mathrm{L}\right)$. Control serum (pool of sera from nonatopic, non-barnacle-allergic individuals) was used in the EAST assay, with negative results $\left(<0.35 \mathrm{kU}_{\mathrm{A}} / \mathrm{L}\right)$.

An analysis using SDS-PAGE immunoblotting under electrophoretic reducing conditions (2-mercaptoethanol)

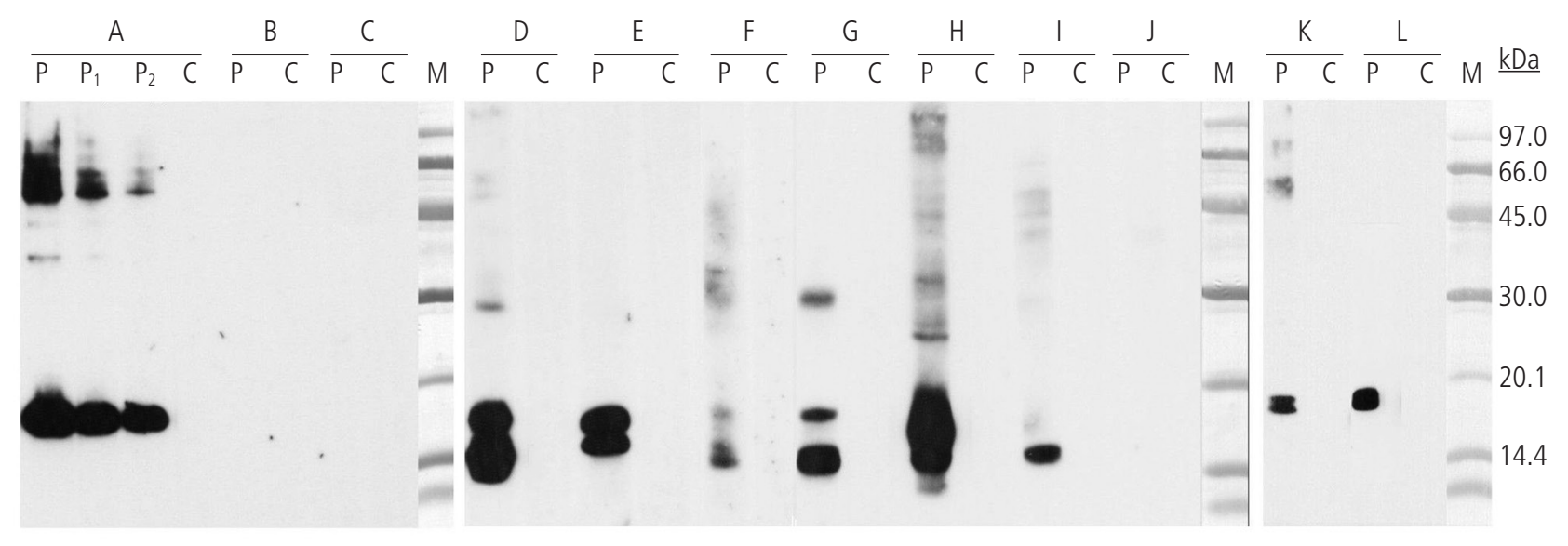

Figure. SDS-PAGE Immunoblotting. A, Boiled barnacle. B, Purified barnacle tropomyosin. C, Purified Der p 10. D, Dermatophagoides pteronyssinus. E, Lepidoglyphus destructor. F, Tyrophagus putrescentiae. G, Blomia tropicalis. H, Glyciphagus domesticus. I, Acarus siro. J, Chortoglyphus arcuatus. K, Penaeus indicus. L, Periplaneta americana. Lanes $P_{1} P_{1}, P_{2}$, patient serum (various dilutions); Lane $C$, control serum (pool of sera from nonatopic, non-barnacleallergic patients); Lane $\mathrm{M}$, molecular mass standards. 
was performed as previously described [5] and revealed IgEbinding proteins of approximately $17-18 \mathrm{kDa}$ in barnacle extracts (raw, boiled), D pteronyssinus, $L$ destructor, $T$ putrescentiae, Blomia tropicalis, Glyciphagus domesticus, Penaeus indicus, P americana, and Acarus siro, and no IgEreactive bands in the $C h$ arcuatus extract. In addition to the high-intensity 17-kDa IgE-binding band, less intense bands of approximately $60 \mathrm{kDa}, 50 \mathrm{kDa}$, and $35 \mathrm{kDa}$ were observed in the barnacle extract, although none were tropomyosin, since no IgE-reactive band was detected in the blotting assay with purified tropomyosins from barnacle and $D$ pteronyssinus (Der p 10) (Figure).

Immunoblotting-inhibition assays were performed using boiled barnacle extract in the solid phase and various crustacean extracts (mites, cockroaches, shellfish) as inhibitors. The extracts of $D$ pteronyssinus, $L$ destructor, Tputrescentiae, $B$ tropicalis, $G$ domesticus, $P$ indicus, $P$ americana, and $A$ siro completely inhibited IgE binding in the barnacle extract (results not shown). The fact that all the barnacle IgE-binding bands were inhibited simultaneously with all the extracts used in the assay leads us to suspect that barnacle bands greater than $17 \mathrm{kDa}$ could be aggregates of the $17-\mathrm{kDa}$ protein.

Finally, the IgE binding protein of approximately $17 \mathrm{kDa}$ from barnacle was identified by mass spectrometry as described elsewhere [6]. Proteins were identified by searching a nonredundant protein sequence database (National Center for Biotechnology Information) using the Mascot program (http://www.matrixscience.com). Research conducted with protein databases led to the identification of the $17-\mathrm{kDa} \operatorname{IgE}$ binding band of barnacle as troponin $\mathrm{C}$.

The cross-reactivity detected between the troponin $\mathrm{C}$ of the barnacle and mites led us to hypothesize that in this case, sensitization by inhalation to troponin $\mathrm{C}$ from mite had predisposed the patient to an allergic reaction due to barnacle consumption.

Over the last decade, troponin has been reported to be an allergen in $T$ putrescentiae (Tyr p 6), $P$ americana (Per a 6), B germanica (Bla g 6), and several species of shellfish crustaceans (Homarus americanus [Hom a 6], Crangon crangon [Cra c 6], Pandalus borealis [Pan b 6], and Chionoecetes opilio [Chi or 6]) [7-10]. However, its allergenic character has not been noted in barnacle and genera of mites that are more common and more significant sensitization agents in our region (eg, Dermatophagoides and Lepidoglyphus species).

The allergy study led us to believe that the allergic symptoms experienced by this patient after ingestion of barnacle were due to sensitization to troponin $\mathrm{C}$. The primary sensitization to this protein had probably been produced by inhalation of troponin $\mathrm{C}$ from house dust mites, minor mites, or both.

It is important to note that although troponin $\mathrm{C}$ has been described as an allergen in the genus Penaeus and also in other crustaceans, the patient we report had no allergic symptoms after prawn ingestion, despite being sensitized to the troponin of some of these species. Given the negative challenge test result with shrimp, we recommended the patient to avoid barnacles only. It is important to highlight that recommendations regarding food avoidance should be tailored.

\section{Funding}

The authors declare that no funding was received for the present study.

\section{Conflicts of Interest}

The authors declare that they have no conflicts of interest.

\section{References}

1. Darwin, Charles (1854). The Balanidae (or Sessile Cirripedes); the Verrucidae, etc. A Monograph of the Sub-class Cirripedia, with figures of all the species. London, UK: The Ray Society.

2. Leung PS, Chow WK, Duffey S, Kwan HS, Gershwin ME, Chu $\mathrm{KH}$. IgE reactivity against a cross-reactive allergen in crustacea and mollusca: Evidence for tropomyosin as the common allergen. J Allergy Clin Immunol. 1996;98:954-61.

3. Moreno Escobosa MC, Alonso Lebrero E, Sánchez Alonso A, Méndez Alcalde J, Rico Díaz MA, García Alvárez G, Bartolomé Zavala B.Barnacle hypersensitivity. Allergol et Immunopathol. 2002:30(2):100-3.

4. Marinho S, Morais-Almeida M, Gaspar A, Santa-Marta C, Pires G, Postigo I, Guisantes J, Martínez J, Rosado-Pinto J. Barnacle allergy: allergen characterization and cross-reactivity with mites. J Investig Allergol Clin Immunol. 2006;16(2):117-22.

5. Fuentes $V$, De Barrio $M$, Rubio $M$, Rodríguez $A$, Martínez MI, Zapatero L, Bartolome B. Non-occupational allergy caused by the Pine Processionary Caterpillar (Thaumetopoea pityocampa). Alergol et Immunopathol. 2004 MarApr;32(2):69-75.

6. Pastor C, Cuesta-Herranz J, Cases B, Pérez-Gordo M, Figueredo $\mathrm{E}$, de las Heras M, Vivanco F. Identification of major allergens in watermelon. Int Arch Allergy Immunol. 2009;149:291-8.

7. Hindley J, Wünschmann S, Satinover SM, Woodfolk JA, Chew FT, Chapman MD, Pomés A. Bla g 6: a tropnin C allergen from Blattella germánica with IgE binding calcium dependence. J Allergy Clin Immunol. 2006;117(6):1389-95.

8. Khantisitthiporn $\mathrm{O}$, Sookrung $\mathrm{N}$, Tungtrongchitr $\mathrm{A}$, Tongtawe P, Bunnag C, Srimanote P, Tapchaisri P, Chaicumpa W. Native troponin-T of the American cockroach (CR), Periplaneta americana, binds to IgE in sera of CR allergic Thais. Asian Pac J Allergy Immunol. 2007;25(4):189-97.

9. Jeong KY, Kim CR, Un S, Yi MH, Lee IY, Park JW, Hong CS, Yong TS. Allergenicity of recombinant troponin $\mathrm{C}$ from Tyrophgagus putrescentiae. Int Arch Allergy Immunol. 2010;151(3)207-13.

10. Sander I, Kespohl S, Merget R, Goldscheid N, Degens PO, Bruning T, Raulf-Heimsoth M. A new method to bind allergens for the measurement of specific IgE antibodies. Int Arch Allergy Immunol. 2005;136:39-44.

I Manuscript received February 8, 2017; accepted for publication March 23, 2017.

Manuel Jorge Rial Prado C/ Coruña $783^{\circ}$

Ferrol (A Coruña), Spain

E-mail: manuterial@gmail.com 


\section{Desensitization to Cyanocobalamin: Rush Protocol}

Alves-Correia $\mathrm{M}^{1}$, Gaspar $\mathrm{A}^{1}$, Borrego $\mathrm{LM}^{1,2}$, Mota $\mathrm{I}^{1}$, MoraisAlmeida $\mathrm{M}^{1}$

${ }^{1}$ Immunoallergy Department, CUF Descobertas Hospital, Lisbon, Portugal

${ }^{2}$ CEDOC, Immunology, NOVA Medical School, Faculty of Medical Sciences, New University of Lisbon, Portugal

J Investig Allergol Clin Immunol 2017; Vol. 27(3): 196-197 doi: 10.18176/jiaci.0160

Key words: Vitamin $\mathrm{B}_{12}$. Allergy. Cyanocobalamin. Desensitization. Rush protocol.

Palabras clave: Vitamina $B_{12}$. Alergia. Cianocobalamina. Desensibilización. Protocolo rush.

Allergy to cyanocobalamin, commonly known as vitamin $\mathrm{B}_{12}$, is uncommon [1-3]. The first report of proven IgE-mediated hypersensitivity to vitamin $B_{12}$ (but not to benzyl alcohol preservative or other preservatives or impurities) $[4,5]$ was made by Hodving in 1968 [6]. The reaction occurs mostly in patients who have already taken several intramuscular drugs [1-3]. Desensitization is mandatory in patients who are allergic to this vitamin and with a clinical indication for vitamin $\mathrm{B}_{12}$ therapy.

There are few protocols in the literature for desensitization to cyanocobalamin [1-3,7]. Apart from a more rapid protocol published in 1997 by Branco-Ferreira et al [1], most protocols have been designed with slow schemes lasting up to 5 days [2] or even 7 weeks $[3,7]$, until a cumulative dose of $1000 \mu \mathrm{g}$ is reached. These protocols are time-consuming and therefore not cost-effective. We developed a shorter protocol that lasts only 2.5 hours.

We report the case of a 61-year-old man with vitamin $B_{12}$ deficiency (malabsorption due to Barrett metaplasia) who had been on replacement therapy for the previous 5 years. Vitamin $B_{12}$ was administered every 2 months with an intramuscular infusion of cyanocobalamin (Permadoze, $1 \mathrm{mg} / \mathrm{mL}$ ) or cobamamide (Jaba B12, $10 \mathrm{mg} / 2 \mathrm{~mL}$ ) according to the commercially available injectable formulation at the time of prescription, which therefore changed over time.
Two hours after the last administration of cyanocobalamin (Permadoze, $1 \mathrm{mg}$ ), the patient developed angioedema of the face and hands with generalized pruritus and urticaria, which remitted after oral intake of levocetirizine $(10 \mathrm{mg})$ and deflazacort $(30 \mathrm{mg})$. He reported never having previously experienced an adverse reaction during treatment.

The patient had a personal history of asthma and allergic rhinitis, with total IgE of $1440 \mathrm{kU} / \mathrm{L}$ and positive results in skin prick tests with house dust mites (Dermatophagoides pteronyssinus, Dermatophagoides farinae, Acarus siro, Blomia tropicalis, Euroglyphus maynei, Lepidoglyphus destructor, and Tyrophagus putrescentiae), pollens (Olea europaea), and cat dander.

At the immunoallergy department, we performed skin tests with injectable cyanocobalamin and cobamamide, which are the currently available formulations of vitamin $\mathrm{B}_{12}$ in Portugal (hydroxycobalamin is not available).

Skin prick tests with both cyanocobalamin and cobamamide were negative with nondiluted solution ( $1 \mathrm{mg} / \mathrm{mL}$ and $5 \mathrm{mg} / \mathrm{mL}$, respectively). Intradermal tests were subsequently performed with both cyanocobalamin and cobamamide, starting at a dilution of $1: 1000$ and progressing 10-fold. Positivity was observed in the immediate reading at 20 minutes [8], at a concentration of 1:10 for both cyanocobalamin and cobamamide. There were no late reactions. First, we performed intradermal tests with cyanocobalamin, which yielded positive results at a concentration of 1:10 (wheal, $10 \mathrm{~mm}$ ), with erythema and pruritus. On the same day, after reading intradermal tests with cyanocobalamin, we performed intradermal tests with cobamamide, which yielded positive results at a concentration of 1:10 (wheal, $8 \mathrm{~mm}$ ) with erythema and pruritus accompanied by facial erythema and periorbital angioedema that promptly reverted after oral intake of ebastine $(20 \mathrm{mg}$ ) and deflazacort ( $30 \mathrm{mg}$ ). Skin test positivity at the immediate reading confirmed the underlying IgEmediated mechanism [8]. Intradermal tests with the solvents were negative. The results of prick and intradermal tests with the same preparations in 2 healthy volunteers were negative.

After obtaining the patient's written informed consent, we scheduled a desensitization protocol in order to reach a 1-mg administration of vitamin $\mathrm{B}_{12}$ on a single day. The protocol (Table), which was modified from Caballero et al [3] and Kartal et al [7], was designed using increasing dilutions of the commercial preparation of cyanocobalamin (Labesfal, $1 \mathrm{mg} / \mathrm{mL}$ ).

Table. Cyanocobalamin Desensitization Rush Protocola

\begin{tabular}{lll}
\hline Dilution/ Concentration & Amount Administered, $\mathrm{mL}$ & Cumulative Dosage, $\mu \mathrm{g}$ \\
\hline $1: 100,10 \mu \mathrm{g} / \mathrm{mL}$ & $0.1 \mathrm{~mL}^{\mathrm{b}} \rightarrow 0.3 \mathrm{~mL}^{\mathrm{b}} \rightarrow 0.6 \mathrm{~mL}^{\mathrm{b}}$ & $10 \mu \mathrm{g}$ \\
$1: 10,100 \mu \mathrm{g} / \mathrm{mL}$ & $0.1 \mathrm{~mL}^{\mathrm{b}} \rightarrow 0.3 \mathrm{~mL}^{\mathrm{b}} \rightarrow 0.6 \mathrm{~mL}^{\mathrm{b}}$ & $100 \mu \mathrm{g}$ \\
$1: 1,1000 \mu \mathrm{g} / \mathrm{mL}$ & $0.1 \mathrm{~mL}^{\mathrm{c}} \rightarrow 0.3 \mathrm{~mL}^{\mathrm{c}} \rightarrow 0.5 \mathrm{~mL}$ & $900 \mu \mathrm{g}$
\end{tabular}

${ }^{a}$ Modified from Caballero et al [3] and Kartal et al [7].

Interval of 15 minutes between subcutaneous injections.

${ }^{\mathrm{C}}$ Interval of 30 minutes between subcutaneous injections. 
The desensitization procedure took place in the day hospital under the supervision of an allergist. Three solutions with different concentrations (1:100, 1:10, and 1:1 [nondiluted drug]) were administered subcutaneously every 15 minutes, except for the last 2 doses, which were separated by an interval of 30 minutes. The total protocol took 2 hours and 30 minutes. A total of 9 subcutaneous injections were administered, with a total cumulative dose of $1010 \mu \mathrm{g}$. Consistent with other authors $[3,7]$, we selected the subcutaneous route because it is less painful than the intramuscular route. No local or systemic adverse reactions were observed, and the patient was discharged 4 hours after the last injection. The medical team contacted the patient within 24 hours. Complete blood counts and serum vitamin $\mathrm{B}_{12}$ levels were normal. The patient's vitamin $\mathrm{B}_{12}$ level increased from $198 \mathrm{ng} / \mathrm{L}$ before desensitization to $296 \mathrm{ng} / \mathrm{L}$ after desensitization. He has since undergone the protocol (1-mg dose) every 2 months with no adverse reactions. Serum vitamin $B_{12}$ has remained at normal levels. The skin tests were repeated 6 months after desensitization and yielded negative results to cyanocobalamin (intradermal tests).

Vitamin $B_{12}$ is an organic complex that is included in a family of compounds called cobalamins, which contain central cobalt ions in a corrin ring. Cobalamins consist of 4 major forms, namely, cyanocobalamin, cobamamide (also known as adenosylcobalamin), hydroxycobalamin, and methylcobalamin. There are reports of patients who react to one form of cobalamin but tolerate an alternative formulation [9]. However, several reports have shown sensitization to all injectable formulas of vitamin $\mathrm{B}_{12}$ and in vitro crossreactivity between all cobalamins $[1-3,7,10]$. In Portugal, the available injectable formulations include cyanocobalamin and cobamamide. Considering these data and the possibility of cross-reactions, we opted for cyanocobalamin, which showed less skin test reactivity, and performed a rapid desensitization protocol, which proved to be very successful.

We report a cyanocobalamin rush desensitization protocol (2.5 hours) that made it possible to reach a cumulative dose of $1 \mathrm{mg}$. The protocol enabled maintenance of an indispensable and very effective treatment. In addition, it was safe, costeffective, and very short.

\section{Funding}

The authors declare that no funding was received for the present study.

\section{Conflicts of Interest}

The authors declare that they have no conflicts of interest.
3. Caballero MR, Lukawska J, Lee TH, Dugué P. Allergy to vitamin B12: Two cases of successful desensitization with cyanocobalamin. Allergy. 2007;62:1341-2.

4. Lagerholm B, Lodin A, Gentele H. Hypersensitivity to phenylcarbinol preservative in vitamin B12 for injection. Acta Allergol. 1958; 12:295-8.

5. Turvey SE, Cronin B, Arnold AD, Twarog FJ, Dioun AF. Adverse reactions to vitamin B12 injections due to benzyl alcohol sensitivity: successful treatment with intranasal cyanocobalamin. Allergy. 2004;59:1023-4.

6. Hodving G. Anaphylactic reaction after injection of vitamin B12. Br Med J. 1968;3:102.

7. Kartal O, Gulec M, Demirel F, Yesillik S, Caliskaner Z, Sener 0 . Vitamin B12 allergy and successful desensitisation with cyanocobalamin: a case report. Allergol Immunopathol (Madr). 2012;40:324-5.

8. Brockow K, Romano A, Blanca M, Ring J, Pichler W, Demoly P. General considerations for skin test procedures in the diagnosis of drug hypersensitivity. Allergy. 2002;57:45-51.

9. Heyworth-Smith D, Hogan PG. Allergy to hydroxycobalamin, with tolerance of cyanocobalamin. Med J Aust. 2002;177:1623.

10. Selva Kumar LS, Thakur MS. Competitive immunoassay for analysis of vitamin B12. Anal Biochem. 2011;418:238-46.

Manuscript received November 12, 2016; accepted for publication March 27, 2017.

\author{
Ângela Gaspar \\ Immunoallergy Department \\ CUF Descobertas Hospital \\ Rua Mário Botas \\ 1998-018 Lisboa, Portugal \\ E-mail: angela.gaspar@sapo.pt
}

\section{References}

1. Branco-Ferreira M, Clode MH, Pereira-Barbosa MA, PalmaCarlos AG. Anaphylactic reaction to hydroxycobalamin. Allergy. 1997;52:118-9.

2. Costa $A C$, Branco-Ferreira $M$, Spínola-Santos $A$, Pedro $E$, Palma-Carlos A, Pereira-Barbosa M. Hipersensibilidade à Vitamina B12 - A possibilidade de dessensibilização. Rev Port Imunoalergologia. 2005;13:177-85. 